\title{
Amblyomma rotundatum (Koch, 1844) (Acari: Ixodidae) two-host life-cycle on Viperidae snakes
}

\author{
Ciclo dioxênico em Amblyomma rotundatum (Koch, 1844) (Acari: Ixodidae) \\ parasitando serpentes da família Viperidae \\ Daniel Sobreira Rodrigues ${ }^{1,2}$; Ricardo Maciel $^{3}$; Lucas Maciel Cunha ${ }^{1}$; \\ Romário Cerqueira Leite ${ }^{4}$; Paulo Roberto de Oliveira ${ }^{4,5 *}$ \\ ${ }^{1}$ Escola de Veterinária, Universidade Federal de Minas Gerais - UFMG \\ ${ }^{2}$ Empresa de Pesquisa Agropecuária de Minas Gerais - EPAMIG \\ ${ }^{3}$ Fundação Ezequiel Dias - FUNED \\ ${ }^{4}$ Laboratório de Pesquisas em Endo e Ectoparasitoses, Departamento de Medicina Veterinária Preventiva, Escola de Veterinária, \\ Universidade Federal de Minas Gerais - UFMG \\ ${ }^{5}$ Study Supervisor \\ Received May 7, 2010 \\ Accepted July 12, 2010
}

\begin{abstract}
Amblyomma rotundatum is an ixodid tick that infests ectothermic animals and reproduces exclusively by parthenogenesis. This tick has been frequently reported to infest reptiles and amphibians, under natural conditions and sometimes in captivity. It was described in Brazil and several other countries of South, Central and North America. Although many studies have reported aspects of its biology, none of them has used regularly either ophidian as hosts, or controlled temperature, humidity and luminosity for parasitic stages. The objective of this experiment was to study the life cycle of $A$. rotundatum feeding on Viperidae snakes under room controlled conditions at $27 \pm 1{ }^{\circ} \mathrm{C}$ temperature, $85 \pm 10 \%$ relative humidity and 12:12 hours photoperiod for parasitic stages, and under B.O.D incubator conditions at $27 \pm 1{ }^{\circ} \mathrm{C}$ temperature, $85 \pm 10 \%$ relative humidity and scotophase for non-parasitic stages. The total duration of the life cycle ranged from 56 to 163 days (mean of 105 days). Two-host life cycle was observed for most of the ixodid population studied.
\end{abstract}

Keywords: Amblyomma rotundatum, two-host, life-cycle, Bothrops, Viperidae.

\section{Resumo}

Amblyomma rotundatum é um carrapato da família Ixodidae, parasito de animais pecilotérmicos, e que se reproduz exclusivamente por partenogênese. Este carrapato é frequentemente relatado infestando répteis e anfíbios em condiçóes naturais e, às vezes, em animais de cativeiro. Ele já foi relatado no Brasil e em vários outros países das Américas do Sul, Central e do Norte. Embora muitos estudos sobre sua biologia tenham sido publicados, nunca foram utilizados ofídios como hospedeiros e, tão pouco, foram realizados ensaios com os estádios parasitários sob condições controladas de temperatura, umidade e iluminaçáo. $\mathrm{O}$ objetivo deste experimento foi estudar o ciclo biológico de $A$. rotundatum se alimentando em serpentes da família Viperidae sob condiçóes ambientais controladas a $27 \pm 1{ }^{\circ} \mathrm{C}$ de temperatura, $85 \pm 10 \%$ de umidade relativa do ar e 12:12 horas de fotoperíodo para estágios parasitários; assim como sob condiçóes iguais a $27 \pm 1{ }^{\circ} \mathrm{C}$ de temperatura, $85 \pm 10 \%$ de umidade relativa do ar e escotofase em estufas de germinaçáo para estádios não parasitários. A duraçẫo total do ciclo de vida variou de 56 a 163 dias (média de 105 dias). Observou-se ciclo dioxênico para a a maior parte da população dos ixodídeos em estudo.

Palavras-chave: Amblyomma rotundatum, dioxênico, ciclo biológico, Bothrops, Viperidae.

\footnotetext{
${ }^{*}$ Corresponding author: Paulo Roberto de Oliveira

Professor Associado, Laboratório de Pesquisas em Endo e Ectoparasitoses,

Departamento de Medicina Veterinária Preventiva, Escola de Veterinária,

Universidade Federal de Minas Gerais - UFMG, Av. Antônio Carlos 6627,

CP 567, CEP 30123-970, Campus da UFMG, Belo Horizonte - MG, Brazil;

e-mail: pro@ufmg.br
} 


\section{Introduction}

The tick $A$. rotundatum is a parasite that infests cold-blooded animals, as some species of amphibians and reptiles, and was first described in literature by Koch (1844 apud ROBINSON, 1926) from a female collected in the state of Pará, Brazil. The origin and significance of males in the life cycle of $A$. rotundatum remain unknown, since this ixodid reproduces exclusively by parthenogenesis (LABRUNA et al., 2005). A. rotundatum is believed to be one of the most ancient ticks of its genus. The small number of laid eggs per gram, observed by Labruna et al. (1997), is believed to be associated to the primitive ticks which evolved along with amphibians and reptiles in the end of the Paleozoic era and beginning of the Mesozoic era (HOOGSTRAL, 1985; OLIVER Jr., 1989).

This parasite is geographically limited to the Americas, which include at the moment the following countries: Brazil, Argentina, Colombia, Bolivia, Peru, Venezuela, Dominican Republic, Guatemala, Panama, Costa Rica, Jamaica, Granada, Martinique, Trinidad and Tobago, Mexico and The United States of America (ROBINSON, 1926; ARAGÃO, 1938; VOLGESANG, DIAS, 1953; JONES et al., 1972; OLIVER Jr. et al., 1993). With the purpose of biological control of flies in sugar-cane plantations in the state of Florida (USA), the introduction of Bufo marinus accidentally also introduced the tick $A$. rotundatum, common parasite of this toad specie (BECKLUND, 1968; OLIVER Jr. et al., 1993).

The infestation with these ticks is extremely pathogenic to hosts, and even in small scales, it can lead them to death. Few studies exist to confirm this hypothesis, but death has been attributed to the inoculation of toxins (HANSON et al., 2007). It is known, though, that the species transmits the hematozoon Hemolivia stelatta in frogs, and that secondary infections and stress caused by the parasitism may easily provoke septicaemia and lead the reptile to death (MADER, 1996). These are the reasons why studies about $A$. rotundatum are extremely important to zoos, bioteries, centers for the extraction of poison and production of snake poison antidotes, investigation of wild cycle diseases and reptile and amphibian medicine. There are studies on the biology of this tick, but none of them has either utilized ophidians as hosts in a systematic form or controlled environmental conditions to assess its parasitic stages, which is crucial, since the influence of temperature on the duration of fixation periods is very much accentuated in cold-blooded animals (BALASHOV, 1972). Thus, the goal of this experiment is to observe the bionomic aspects of all the stages of development of the species in question, using Viperidae Snakes as hosts, under controlled condition of $27 \pm 1{ }^{\circ} \mathrm{C}$ temperature, 75 to $95 \%$ relative humidity and photoperiod of 12 hours for parasitic stages and scotophase for non-parasitic stages.

\section{Material and Methods}

The first step to set up a laboratory colony was to acquire A. rotundatum engorged females. With this goal in mind, a specimen of Bothropoides neuwiedi (Wagler, 1824) and another of Rhinocerophis alternatus (Duméril, Bibron, Duméril, 1854), captured in nature and taken to the center for the production of ophidian poison antidote - FUNED (Ezequiel Dias Foundation) - Belo Horizonte, Brazil, were placed in separate boxes to spontaneously drop off engorged females. Six females were obtained, identified according to Robinson (1926) and Aragão and Fonseca (1961), individually accommodated in Petri dishes and incubated in a BOD incubator at $27^{\circ} \mathrm{C}$ temperature, $95 \%$ relative humidity and scotophase. The laid eggs were placed in plastic syringes with the anterior extremity clipped off and sealed with hydrophilic cotton. The obtained larvae were used to produce ticks for this experiment.

Seven Viperidae snakes were kept in captivity to carry out experimental infestations and a boa snake (Boa constrictor) to produce larvae and females. Sex and age were not taken into account, snakes were identified (BÉRNILS, 2010), evaluated according to overall heath and absence of ectoparasites, and weighted before being submitted to experimentation. Three experimental infestations were carried out: the first with 150 larvae per host, the second with five females per host, and the third with 150 larvae and five females per host. One $R$. alternatus and two Bothropoides jararaca (Wied, 1824) specimens were utilized in the first infestation. Conspecifics adult ticks were utilized to infest one Bothrops moogeni (Hoge, 1966), one B. newiedi, and two B. jararaca specimens. The same Viperidae host specimens of the second infestation were parasitized at the third inoculation.

To carry out the experimental infestation with ticks, the restraint of each host was necessary. This task was accomplished by making the ophidian enter the first third of its body into a transparent tube, which was then immobilized manually by holding both the body of the animal and the tube (Figure 1). After this procedure, the medium third of each serpent was wrapped with a flannel strip of approximately $10 \mathrm{~cm}$ wide and $20 \mathrm{~cm}$ long and tied with adhesive tape forming a cylinder. One of the ends of the cylinder was closed with adhesive tape and the other kept open until the ticks were introduced (Figure 2). It was then sealed to keep the ticks from dispersing. The adult specimens, between 20 and 50 days after molting from nymphs to females, were divided into groups of five females on Petri dishes, 30 minutes before infestation. For this purpose, the groups with best motility were chosen. Larvae between 20 and 50 days after eclosion, accommodated in plastic syringes, were inoculated by pressing the syringe embolus towards the interior of the bag, leaving there as well the cotton placed in the bottom of the syringe. After three days, all the hosts were contained again to withdraw the flannel strips.

The hosts were kept in a room, accommodated in white or transparent plastic boxes, with the superior edges taped up with double-faced adhesive tape, numbered lids, potable water ad libitum and with one rough stone to help in the physiological process of skin change. Adult mice or little rats were made available every 15 to 20 days for feeding. The room with an area of $11.5 \mathrm{~m}^{2}$ and $3 \mathrm{~m}$ high was equipped with an electric 12 watts heater-fan controlled by an analogical thermostat with a $1.5^{\circ} \mathrm{C}$ differential; a medium size automatic-electric vaporizer, kept on 12 to 14 hours a day; and an analogical timer set to turn on four fluorescent lights at 6:00 AM and turn off at 6:00 PM. Two digital thermo-hygrometers placed at different points of the room, close to the hosts, also monitored the temperature and relative humidity. 


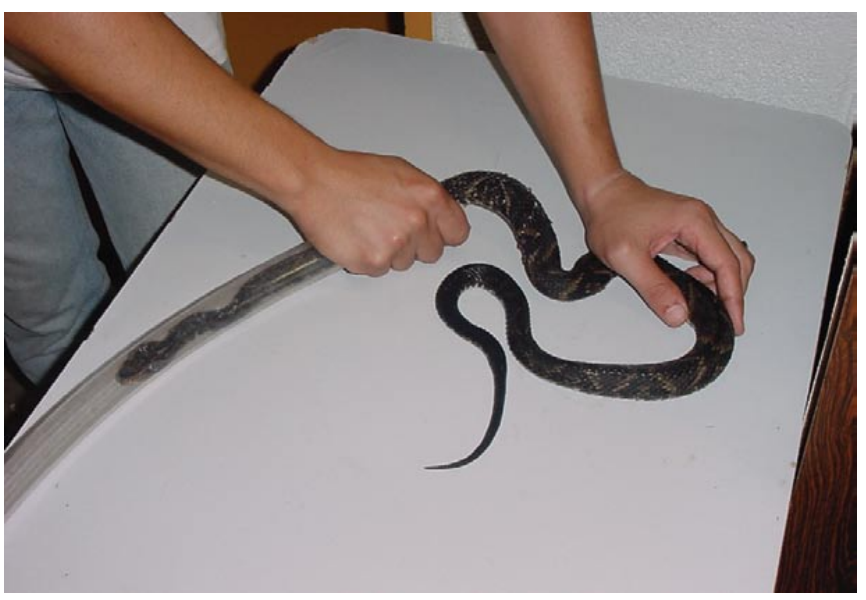

Figure 1. Ophidian's manual immobilization by holding snake's body into a transparent tube.

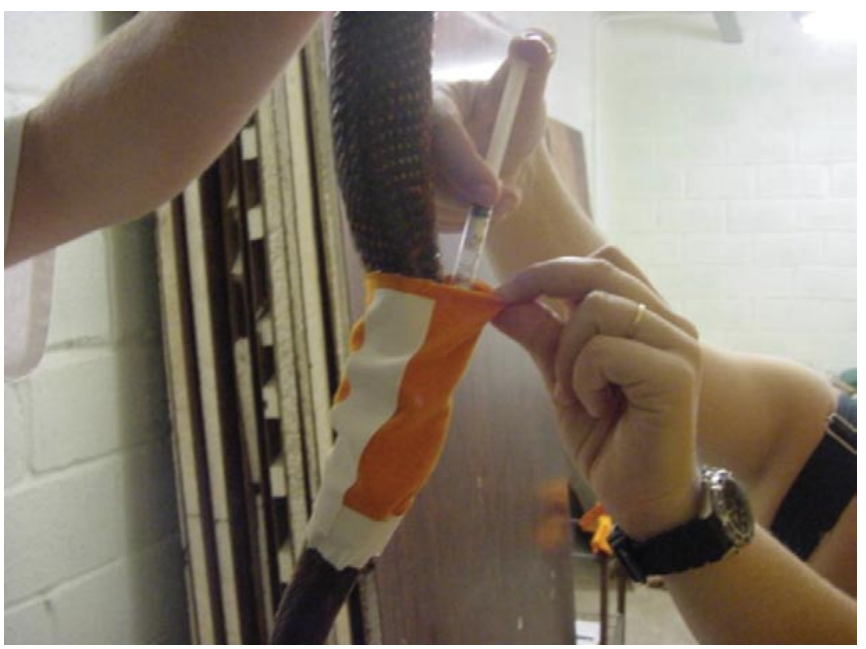

Figure 2. A. rotundatum larvae infestation in a Viperidae snake containing an alimentation chamber in its body. This apparatus were constructed wrapping a flannel strip tied with adhesive tape.

Observation took place daily as each serpent was transferred to a handling box to inspect the container. The following bionomic aspects were observed during the experiment: parasitic periods and recovery rates of larvae, nymphs and female; premolt periods and index of ecdysis of larvae and nymphs; weight of ovipositions and engorged females; pre-oviposition, oviposition, and egg incubation periods; larval hatchability; efficiency rates of female ticks in converting their food reservoir to larvae and eggs.

The recovery rate was calculated by dividing the number of specimens recovered by the total placed on the host. Although no infestations with nymphs were carried out, the observed "larvae to nymph parasitic periods" means the interval between larvae infestation and nymph drop-off times. The differences between the averages of larvae to nymph parasitic periods and the interval containing larval parasitic and premolt larval periods were utilized to estimate the nymph's parasitic period.

The efficiency rates of female ticks in converting their food reservoir to eggs (ERCE) and the efficiency rates of female ticks in converting their food reservoir to larvae (ERCL) were calculated, according to Szabó et al. (1995), by taking into account the weight of egg mass (EW), weight of engorged females (FW) and larval hatchability (LH), as follows (Equation 1):

$$
\mathrm{ERCE}=\frac{\mathrm{EW} \times 100}{\mathrm{FW}} \quad \mathrm{ERCL}=\frac{\mathrm{EW} \times \mathrm{LH}}{\mathrm{FW}}
$$

Descriptive statistics was utilized in the evaluation of all parameters observed (SAMPAIO, 2002).

\section{Results}

The recovery rate of non-engorged larvae, engorged larvae, non-engorged nymphs, engorged nymphs and engorged females was of $20,8,6,11$ and $37 \%$ respectively. From the total of recovered specimens after infestation with larvae, $45 \%$ did not do or complete blood repast, $18 \%$ had the form of engorged larvae, $4 \%$ was non-engorged nymphs and 33\% engorged nymphs. Other observed parameters are shown in the Table 1 and the Figure 3 shows the drop-off dynamics in the immature stages of $A$. rotundatum, thus demonstrating the occurrence of the tick's two-host cycle. Seven nymphs at pre-molting period were detached from a host which died during the experiment. Including it was also possible to recover one non-engorged female from another host. These facts indicates the possibility of $A$. rotundatum realize one-host cycle either.

A $100 \%$ death rate of the Viperidae hosts was registered. Clinical symptoms included anorexia, weakening, dysecdysis, anemia, oral congestion, edema and caseous exudate, mucous oral and nasal discharges, diarrhea, dermatitis and cutaneous abscesses. Post-mortem alterations included diagnosis of stomachitis, pneumonia, enteritis and septicaemia, the association of all them being the most frequent cause. All animals presented stomachitis symptoms. The $B$. constrictor utilized to maintain $A$. rotundatum colony did not died possibly because its higher length and weight than Viperidae snakes, as well the low number of ticks inoculated.

\section{Discussion}

Values recorded in this study with regards to parasitic periods of larvae, nymphs and females were higher than the values described in literature thus far by Rohr (1909), Aragão (1912), Oba and Shumaker (1983) and Amorim et al. (1996). This difference must be related to the different environmental conditions during the experiments. Oba and Shumaker (1983) observed full variation of the cycle of 135 to 250 days under temperature of $27^{\circ} \mathrm{C}$ and $80 \% \mathrm{RH}$ for non-parasitic stages and environmental conditions for parasitic stages. In this study, under controlled condition of $27 \pm 1{ }^{\circ} \mathrm{C}$ temperature and 75 to $95 \%$ relative humidity, it took 13 days for females engorging period and a variation of 56 to 163 days for the full biological cycle. The shortest periods observed in higher room temperature confirmed the strong influence of temperature on the periods of tick fixation in cold-blooded animals. Therefore, recording the room temperature becomes crucial in the observation and comparison of the fixation periods of this tick. Temperature 
Table 1. Bionomic parameters of Amblyomma rotundatum ticks feeding on Viperidae ophidians under laboratory conditions (27 $\pm 1{ }^{\circ} \mathrm{C}, 85 \pm 10 \% \mathrm{RH}$ and scotophase).

\begin{tabular}{lcc}
\hline \multicolumn{1}{c}{$\begin{array}{c}\text { Biological } \\
\text { parameter }\end{array}$} & $\begin{array}{c}\text { Mean } \pm \text { standard } \\
\text { deviation }\end{array}$ & $\begin{array}{c}\text { Variation } \\
\text { width }\end{array}$ \\
\hline Larval parasitic period (days) & $15.58 \pm 5.97$ & 9 to 31 \\
Larval premolt period (days) & $12.88 \pm 1.96$ & 10 to 17 \\
Nymph parasitic period (days) & 10 & - \\
Larval to nymph parasitic period (days) & $38 \pm 5.45$ & 25 to 57 \\
Nymph premolt period (days) & $16.64 \pm 0.86$ & 15 to 19 \\
Female engorging period (days) & $12.60 \pm 3.79$ & 6 to 21 \\
Pre-oviposition period (days) & $6.07 \pm 1.94$ & 4 to 10 \\
Oviposition period (days) & $18.36 \pm 5.44$ & 9 to 29 \\
Egg incubation period (days) & $30.40 \pm 7.57$ & 13 to 46 \\
Weight of engorged females (mg) & $1021 \pm 255$ & 429 to 1338 \\
Weight of egg mass (mg) & $488 \pm 183$ & 143 to 762 \\
Larval hatchability (\%) & $87 \pm 6$ & 75 to 95 \\
ERCE $(\%)^{\mathrm{a}}$ & $47 \pm 12$ & 28 to 59 \\
ERCL $(\%)^{\mathrm{b}}$ & $42 \pm 12$ & 25 to 54 \\
Total life cycle period (days) & 105 & 56 to 163 \\
\hline
\end{tabular}

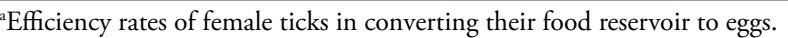

${ }^{b}$ Efficiency rates of female ticks in converting their food reservoir to larvae.

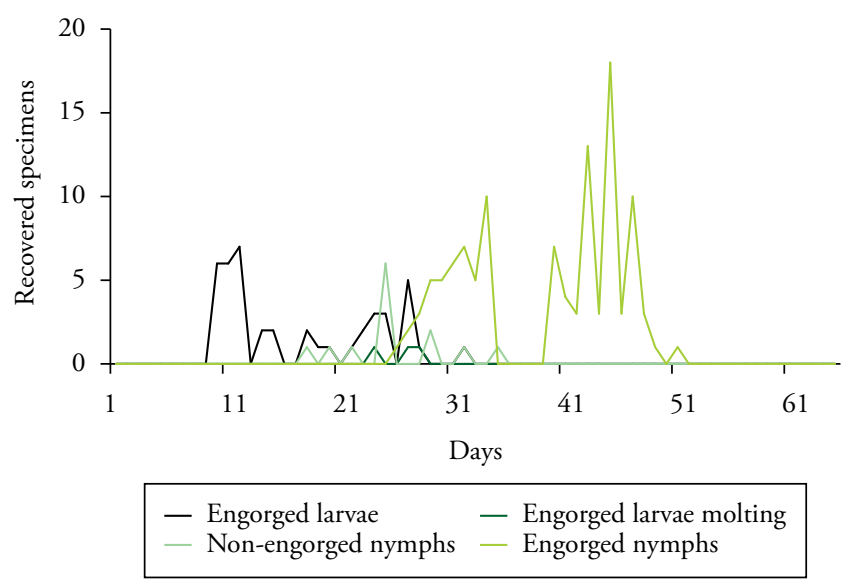

Figure 3. Drop-off dynamics of immature stages of $A$. rotundatum after infestation with larvae on Viperidae ophidians, under controlled laboratory conditions $\left(27 \pm 1{ }^{\circ} \mathrm{C}, 85 \pm 10 \% \mathrm{RH}\right.$ and scotophase).

control, consequently, allows these parameters to be evaluated more accurately. The remaining values observed regarding bionomical aspects of non-parasitic stages and reproductive parameters were close to those cited in literature under temperature of $27{ }^{\circ} \mathrm{C}$ and $80 \%$ RH by Oba and Shumaker (1983). It was possible to observe in this study the highest weight of an engorged female and oviposition ever described within the species.

Few species of ticks undergo a cycle on two hosts such as A. rotundatum. Some species of the type Hyalomma $(H$. detritum, $H$. anatolicum, $H$. scupense and $H$. plumbeum) and the Rhipicephalus bursa are mentioned as examples (BALASHOV, 1972; SONESHINE, 1993). Balashov (1972) emphasizes that some kinds of ticks known to undergo a two-host cycle, may have three-host or one-host cycles depending on the host. Working with $A$. rotundatum, only Aragão
(1912) observed the occurrence of two-host cycle by employing frogs to feed larvae, and noticing the same phenomenon also when utilizing an ophidian and chelonian as hosts. From 1924 on, all studies assessing the immature stages of this tick utilized frogs as hosts and did not observe occurrence of ecdysis in the animal, thereby characterizing it as three-host (OBA; SHUMAKER, 1983), despite the observations Aragão (1912). Taking into account all of these analyses, $A$. rotundatum tends to present three-host behavior when fed on frogs, and when infesting ophidians and chelonians, part of the population presents two-host behavior and the other three-host. Even though no engorged female originated from infestation with larvae was recuperated in this study, 7 nymphs were collected molting on the host, plus a young female. This detail suggests that, in a natural setting, a percentage of the population must also undergo one-host life-cycle, since lower temperatures are associated with higher ecdysis rates on the host (BALASHOV, 1972).

In this experiment, the number of larvae and females inoculated was determined by descriptions as done by Rohr (1909), Aragão (1912) and Amorim et al. (1996), where the hosts frequently died after infestation with this class of tick. Even then, despite the small quantity of ticks inoculated per host, all of them died. The symptoms observed are compatible with the available information on the clinical aspects of ectoparasitism in reptiles. Infestation by ectoparasites is commonly associated with loss of appetite, depression, dysecdysis, dermatitis, ulcers and abscesses. These conditions enough provoke immunosuppression and occurrence of stomachitis, pneumonia, enteritis, septicaemia, and animal death (MADER, 1996). However, one should not discard the hypotheses of inoculation of toxins and pathogenic microorganisms by the tick, since Hanson et al. (2007) describes one case of tick paralysis caused by an $A$. rotundatum female in a southern black racer, Coluber constrictor priapus, wild-caught in the Florida Keys.

It is concluded that $A$. rotundatum presents a two-host life-cycle when it obtain a blood meal in Viperidae Snakes, and more bioassays are necessary to verify the hypothesis that this tick specie tends to present a two-host life cycle when the reptiles are the hosts.

\section{Acknowledgements}

This study was sponsored by CNPq (Conselho Nacional de Desenvolvimento Científico e Tecnológico), Brazil.

\section{References}

AMORIM, M. et al. Biologia de Amblyomma rotundatum Koch,1844 (Acari: Ixodidae) sob condiçôes de laboratório: dinâmica de infestação de fêmeas não alimentadas em Crotalus durissus (L.). Revista da Universidade Rural, Série Ciência e Vida, v. 18, n. 1-2, p. 35-36, 1996.

ARAGÃO, H. B. Contribuição para a sistemática e biologia dos ixodidas. Partenogênese em carrapatos. Amblyomma agamum n. sp. Memórias do Instituto Oswaldo Cruz, v. 4, p. 96-119, 1912.

ARAGÃO, H. B. Nota sobre ixodideos da Republica Argentina. Memórias do Instituto Oswaldo Cruz, v. 33, n. 2, p. 319-327, 1938. 
ARAGÃO, H. B.; FONSECA, F. Notas de ixodologia. IX. O complexo ovale do gênero Amblyomma. Memórias do Instituto Oswaldo Cruz, v. 59, p. 131-148, 1961.

BALASHOV, Y. S. Bloodsuking ticks (Ixodoidea) - vectors of diseases of man and animals. Miscellaneous Publications of the Entomological Society of America, v. 8, p. 1-337, 1972.

BECKLUND, W. W. Ticks of veterinary significance found on imports in the United States. The Journal of Parasitology, v. 54, n. 3, p. 622-628, 1968.

BÉRNILS, R. S. (Org.). Brazilian reptiles - List of species. 2010. Disponível em: <http://www.sbherpetologia.org.br/>. Acesso em: 3 ago. 2010.

HANSON, B. A. et al. Tick Paralysis of a Snake Caused by Amblyomma rotundatum (Acari: Ixodidae). Journal of Medical Entomology, v. 44, n. 1, p. 155-157, 2007.

HOOGSTRAAL, H. Argasid and Nuttalliellid ticks as parasites and vectors. Advances in Parasitology, v. 24, p. 135-238, 1985.

JONES, E. K. et al. The ticks of Venezuela (Acarina: Ixodoidea) with a key to the species of Amblyomma in the western hemisphere. Brigham Young University Science Bulletin. Biological Series, v. 7, p. 1-40, 1972.

LABRUNA, M. B.; LEITE, R. C.; OLIVEIRA, P. R. Study of weight of eggs from six Ixodid species from Brazil. Memórias do Instituto Oswaldo Cruz, v. 92, n. 2, p. 205-207, 1997.

LABRUNA, M. B.; TERRRASSINI, F. A.; CAMARGO, L. M. A. First report of the male of Amblyomma rotundatum (Acari: Ixodidae) from a field-collected host. Journal of Medical Entomology, v. 42, n. 6, p. $945-947,2005$.
MADER, D. R. Reptile Medicine and Surgery. Philadelphia: W.B. Saunders, 1996.512 p.

OBA, M. S. P.; SHUMAKER T. T. S. Estudo da biologia de Amblyomma rotundatum (Koch, 1844), em infestaçóes experimentais de Bufo marinus (L., 1758) sob condiçóes variadas de umidade relativa e temperatura do ar. Memórias do Instituto Butantan, v. 47/48, p. 195-204, 1983.

OLIVER Jr., J. H. Biology and systematics of ticks (Acari: Ixodidae). Annual Review of Ecology and Systematics, v. 20, p. 397-430, 1989.

OLIVER Jr., J. H. et al. Establishment of the foreign parthenogenetic tick Amblyomma rotundatum (Acari: Ixodidae) in Florida. The Journal of Parasitology, v. 79, n. 5, p. 786-790, 1993.

ROBINSON, L. E. The genus Amblyomma. London: Cambridge University Press, 1926. 301 p.

ROHR, C. J. Estudos sobre Ixodidae do Brasil. Rio de Janeiro: Instituto Oswaldo Cruz, 1909. 220 p.

SAMPAIO, I. B. M. Estatística aplicada à experimentaçáo animal. 2. ed. Belo Horizonte: FEPMVZ, 2002. 265 p.

SONESHINE, D. E. Biology of ticks. New York: Oxford University Press, 1993. $465 \mathrm{p}$.

SZABÓ, M. P. J. et al. Differences in the acquired resistance of dogs, hamsters, and guinea pigs to repeated infestations with adult ticks Rhipicephalus sanguineus (Acari: Ixodidae). Brazilian Journal Veterinary Research and Animal Science, v. 32, n. 1, p. 43-50, 1995.

VOGELSANG, E. G.; DIAS, J. A. T. S. Contribución al estúdio de la fauna ixodológica de Venezuela. Revista de Medicina Veterinaria y Parasitologìa, v. 12, p. 3-62, 1953. 